\title{
KUALITAS DAGING DOMBA YANG DIBERI PAKAN SILASE LIMBAH SAYURAN
}

\author{
The Quality of Lamb Meat which were Fed by Vegetables Waste Silage
}

\author{
A. Falahudin dan O. Imanudin \\ Major of Animal Husbandry, Faculty of Agriculture, Majalengka University \\ K.H. Abdul Halim No. 103 Majalengka \\ e-mail : aaffalahudin@ymail.com
}

\begin{abstract}
The objective of this research is to get information the quality of lamb meat fed with vegetables waste silage. The experiments was conducted using 24 local male sheep 8 - 10 months old with weight between 15 - $20 \mathrm{~kg}$. The experimental design used was Completely Randomized Design with 6 treatments and 4 replications. The treatments applied were as follows: T0 $=100 \%$ green grass $+0 \%$ vegetable waste silage $+T 1=80 \%$ green grass $+20 \%$ vegetable waste silage, $T 2=60 \%$ forage grass $+40 \%$ vegetable waste silage, $T 3=40 \%$ forage grass $+60 \%$ vegetable waste silage, $T 4=20 \%$ forage grass $+80 \%$ vegetable waste silage and $75=0 \%$ forage grass $+100 \%$ vegetable waste silage. The experiment was carried out for 6 weeks with a 2-week adaptation period. The results showed that vegetable waste silage significantly different results on dry matter consumption, daily weight gain and meat protein, but did not provide significant results for the physical quality of male local lamb meat such as color, weight loss and $\mathrm{pH}$. The best treatment is forage feed $60 \%$ and vegetable waste silage $40 \%$ with dry matter consumption of $720.38 \mathrm{~g} /$ day, daily body weight $88.18 \mathrm{~g} /$ day, meat protein $21.05 \%$, color of meat bright red, weight loss $28.57 \%$ and $\mathrm{pH} 5.70$.
\end{abstract}

Keywords: Silage, Vegetable Waste, Dry Matter Consumption, Daily Weight Gain, Quality of Lamb Meat

\section{PENDAHULUAN}

Prospek pengembangan domba di Indonesia cukup potensial. Hal tersebut dikarenakan di samping untuk memenuhi permintaan domba di dalam negeri juga memiliki peluang sebagai komoditas ekspor. Oleh karena itu, diperlukan peningkatan produktivitas domba baik secara kualitas maupun kuantitas.

Produktivitas domba salah satunya sangat tergantung dari ketersediaan pakan hijauan khususnya rumput sepanjang waktu. Indonesia merupakan negara tropis yang memiliki 2 musim yaitu hujan dan kemarau. Oleh karena itu, timbul permasalahan ketersediaan hijauan rumput pada saat musim kemarau sangat sedikit, sehingga produktivitas domba akan mengalami penurunan. Salah satu potensi pakan pengganti hijauan yang belum termanfaatkan adalah limbah sayuran.

Limbah sayuran sebaiknya diolah terlebih dahulu sebelum diberikan sebagai pakan ternak karena palatabilitasnya sangat rendah dan kadar airnya yang tinggi menyebabkan mudah busuk. Salah satunya dengan menggunakan teknologi pakan silase. Hal tersebut bertujuan untuk meningkatkan palatabilitas dan mengawetkan limbah sayuran, sehingga dapat mengatasi kesulitan mendapatkan pakan hijauan pada musim kemarau.

Bahan yang mengalami proses fermentasi mempunyai nilai kecernaan yang lebih baik dari bahan asal. Hal ini disebabkan fermentasi menghasilkan enzim-enzim tertentu yang dapat menguraikan protein menjadi asam amino yang mudah diserap tubuh dan dimanfaatkan untuk pertumbuhan, sehingga dapat meningkatkan kualitas dan kuantitas daging. Kualitas daging biasanya berkaitan erat dengan sifat fisik daging. Hal tersebut dikarenakan kualitas daging dapat diartikan sebagai ukuran sifat - sifat daging yang dikehendaki dan dinilai oleh konsumen. Sifat sifat daging yang berpengaruh terhadap kualitas daging yaitu warna, $\mathrm{pH}$ dan susut masak (cooking loss).

Limbah sayur pasar tradisional memiliki kandungan protein kasar 12,64 - 23.50\% (Muktiani et al., 2007). Hal tersebut menunjukkan bahwa kandungan protein kasar limbah sayur lebih tinggi dibanding rumput alam yang hanya berprotein kasar 8,59\%. Soeparno (2005) menyatakan bahwa peningkatan kualitas protein dalam pakan akan meningkatkan protein dalam tubuh. Protein dalam tubuh tersebut akan digunakan untuk pembentukan massa daging dan kualitas daging, maka penelitian ini dilakukan. 


\section{MATERI DAN METODE}

\section{Materi}

Penelitian dilaksanakan di Peternakan Domba milik Aaf Falahudin, S.Pt., M.Si bertempat di Desa Leuwikidang Kecamatan Kasokandel Kabupaten Majalengka, Jawa Barat. Penelitian ini menggunakan 24 ekor domba lokal jantan umur $<1$ tahun yang ditempatkan dalam kandang individual berukuran $0,6 \times 1 \mathrm{~m}^{2}$ dan dilengkapi dengan tempat pakan dan minum. Pakan yang diberikan adalah rumput lapang dan silase limbah sayuran. Bahan tambahan yang digunakan dalam pembuatan silase limbah sayuran adalah dedak padi, molase dan probiotik EM-4. Alat yang digunakan adalah perlengkapan pembuatan silase sayuran (drum/silo, plastik dan mesin pencacah), $\mathrm{pH}$ meter, timbangan analitik, Meat Colour Card, aquades, plastik polyethene, alat masak dan perlengkapan uji protein. Variabel yang diamati adalah konsumsi pakan, pertumbuhan bobot badan harian, protein daging dan sifat fisik daging (warna, $\mathrm{pH}$ dan susut masak).

\section{Metode}

Penelitian dilaksanakan dengan metode eksperimen yang disusun berdasarkan Rancangan Acak Lengkap (RAL) dengan 6 perlakuan dan 4 ulangan. Perlakuan yang diterapkan adalah sebagai berikut : T0 (100\% hijauan rumput $+0 \%$ silase limbah sayuran), T1 (80\% hijauan rumput + $20 \%$ silase limbah sayuran), T2 (60\% hijauan rumput $+40 \%$ silase limbah sayuran), T3 (40\% hijauan rumput $+60 \%$ silase limbah sayuran), T4 $(20 \%$ hijauan rumput $+80 \%$ silase limbah sayuran), dan T5 (0\% hijauan rumput $+100 \%$ silase limbah sayuran).

Kegiatan penelitian dimulai dengan persiapan kandang terlebih dahulu menggunakan kandang individual ukuran 0,6 m x $1 \mathrm{~m}$. Kandang dilengkapi dengan tempat makan dan minum serta paranet yang ditempatkan dibawah kandang untuk menampung feses domba. Kandang dibersihkan dan disemprot menggunakan desinfektan untuk meminimalisir keberadaan bakteri atau parasit yang masih menempel di kandang akibat pemeliharaan sebelumnya, selanjutnya dilakukan pembuatan silase dengan menggunakan starter EM-4 sebanyak 0,5\% (medium cair), dan aditif molase $2,5 \%$ serta dedak padi sebanyak $30 \%$, diperam (difermentasi) selama 7 hari. Proses pembuatan silase pada limbah sayuran pasar antara lain sebagai berikut:

1. Limbah sayuran dipilah yang masih bagus dan dilanjutkan dengan pembersihan menggunakan air yang mengalir.
2. Limbah sayuran dicacah terlebih dahulu lalu dilayukan sebentar.

3. Limbah sayuran sebanyak $70 \%$ dicampurkan dengan bahan - bahan aditif berupa dedak padi sebanyak $30 \%$, molase $2,5 \%$ serta $0,5 \%$ probiotik EM-4 dan diaduk sampai rata.

4. Bahan yang telah tercampur rata dimasukkan ke dalam silo/drum plastik sedikit demi sedikit sambil dilakukan pemadatan (sambil diinjakinjak) agar tidak ada lagi udara diantara tumpukan bahan silase, lalu ditutup rapat.

5. Silo ditempatkan di tempat yang sejuk untuk proses fermentasi selama 1 minggu.

6. Setelah silase jadi dapat dikeluarkan dari silo untuk diberikan pada ternak, sebelum diberikan pada ternak perlu diangin-anginkan atau dibiarkan terlebih dahulu selama beberapa jam.

Domba lokal jantan sebanyak 24 ekor ditimbang terlebih dahulu menggunakan timbangan elektrik sebelum dilakukan pemberian pakan perlakuan, kemudian bulu domba dicukur dan dimandikan dengan air bersih. Domba diberikan obat cacing Albendazol dan vitamin BKompleks.

Pemberian pakan baik hijauan rumput maupun silase limbah sayuran pasar dilakukan dua kali setiap hari yaitu pada pagi dan sore hari sebanyak 4\% BK (bahan kering) sesuai bobot badannya. Pemberian silase limbah sayuran diberikan terlebih dahulu, sedangkan hijauan diberikan setelah silase limbah sayuran. Sebelum pemberian ransum dilakukan, terlebih dahulu dibersihkan dari sisa pakan dan ditimbang. Air minum diberikan secara ad. libitum. Domba lokal jantan diadaptasikan pada perlakuan pakan selama 2 minggu dan pengamatan konsumsi pakan dan pertumbuhan bobot badan dilakukan selama 4 minggu.

Semua data yang diperoleh dianalisis secara statistik menggunakan analisis variansi dengan bantuan program SPSS versi 16 dan apabila ada perbedaan antar perlakuan dilanjutkan dengan Uji Wilayah Ganda Duncan (Steel dan Torrie, 1993).

\section{HASIL DAN PEMBAHASAN}

\section{Konsumsi Pakan}

Konsumsi pakan merupakan ukuran untuk mengetahui jumlah pakan yang dikonsumsi seekor ternak setiap ekor per hari. Konsumsi pakan yang baik sangat dipengaruhi oleh kualitas pakan yang dikonsumsi ternak. Semakin baik kualitas pakannya, maka semakin baik pula tingkat kesukaan (palatabilitas) ternak yang mengkonsumsinya. Rataan konsumsi bahan 
kering harian domba lokal jantan selama penelitian dari masing-masing perlakuan dapat dilihat pada Tabel 1 .

Data pada Tabel 1 menunjukan bahwa konsumsi bahan kering domba lokal jantan yang diberi substitusi pakan silase limbah sayuran 20\%, $40 \%$ dan $60 \%$ nyata lebih tinggi dibandingkan dengan $100 \%$ rumput lapangan. Akan tetapi, pemberian silase limbah sayuran sebanyak $80 \%$ dan $100 \%$ menyebabkan konsumsi bahan kering lebih rendah dibandingkan dengan domba yang diberi pakan $100 \%$ rumput lapangan.

Konsumsi bahan kering tertinggi yaitu pada perlakuan $60 \%$ rumput lapangan $+40 \%$ silase limbah sayuran sebesar 720,38 g/ekor/hari. Hal ini diduga karena aroma silase limbah sayuran sangat mempengaruhi palatabilitas ternak dalam mengkonsumsinya. Durand (1989) melaporkan bahwa tingkat konsumsi ditentukan oleh faktor aroma ransum. Selain itu, menurut Rahman (2008), faktor-faktor yang mempengaruhi tingkat kosumsi pakan antara lain hewan ternak itu sendiri, nilai palatabilitas pakan yang diberikan, kebutuhan ternak terhadap nutrisi pakan dan lingkungan tempat ternak tersebut dipelihara.

Konsumsi bahan kering terendah adalah pada pemberian $100 \%$ silase limbah sayuran yaitu sebesar 298,58 g/ekor/hari. Hal ini diduga karena ternak tidak terbiasa mengkonsumsi silase limbah sayuran sepenuhnya untuk mencukupi kebutuhan hidupnya, sehingga memerlukan waktu yang cukup lama untuk ternak terbiasa mengkonsumsi pakan yang baru. Tingkat konsumsi yang rendah ini diakibatkan palatabilitas ternak terhadap silase limbah sayuran yang rendah. Siregar (1996) dalam Nanda (2011) menyatakan bahwa angka pemberian hijauan silase sekitar $4 \%$ dari bobot badan ternak ruminansia serta pemberian silase tidak akan dapat menggantikan keseluruhan hijauan segar.

Pemberian silase limbah sayuran pada level $100 \%$ menyebabkan penurunan tingkat konsumsi yang sangat nyata. Hijauan sangat diperlukan pada ternak ruminansia untuk proses memamah biak, sehingga dapat menetralkan tingkat keasaman hasil fermentasi. Oleh karena itu, pemberian pakan $100 \%$ silase limbah sayuran nyata menyebabkan domba menderita sakit dan konsumsi pakan akan semakin turun. Permentan (2006) menyatakan bahwa pemberian silase pada ternak ruminansia tidak dianjurkan melebihi dari 2/3 dari jumlah pakan kasar.

\section{Pertambahan Bobot Badan Harian}

Pertambahan bobot badan domba sangat dipengaruhi oleh kualitas pakan yang dikonsumsi ternak. Pemberian pakan yang berkualitas rendah dapat menyebabkan fungsi rumen menjadi tidak baik, karena bakteri yang terdapat di dalam rumen kurang optimum. Tingkat pertumbuhan seekor ternak sangat tergantung berapa jumlah nutrien yang dikonsumsi dan dimanfaatkan oleh ternak serta dapat dilihat melalui pertambahan bobot sebagian urat daging dan jaringan lainnya. Rataan pertambahan bobot badan harian domba lokal jantan selama penelitian dari masing-masing perlakuan dapat dilihat pada Tabel 1 .

Tabel 1. Konsumsi Bahan Kering dan PBBH Domba Lokal Jantan

\begin{tabular}{lrrrrrr}
\hline Parameter & T0 & \multicolumn{1}{c}{ T1 } & T2 & T3 & \multicolumn{1}{c}{ T4 } & \multicolumn{1}{c}{ T5 } \\
\hline Konsumsi BK (g/ekor/hari) & $667,96^{\mathrm{a}}$ & $697,59^{\mathrm{a}}$ & $720,38^{\mathrm{a}}$ & $714,48^{\mathrm{a}}$ & $473,49^{\mathrm{b}}$ & $298,58^{\mathrm{c}}$ \\
PBBH (g/ekor/hari) & $61,13^{\mathrm{a}}$ & $80,75^{\mathrm{a}}$ & $88,18^{\mathrm{a}}$ & $71,00^{\mathrm{a}}$ & $-33,00^{\mathrm{b}}$ & $-127,00^{\mathrm{c}}$ \\
\hline
\end{tabular}

Keterangan : Superskrip yang berbeda pada baris yang sama menunjukan perbedaan yang nyata $(\mathrm{P}<0,05)$

Hasil uji beda nyata Duncan berdasarkan Tabel 1 menunjukan bahwa rataan pertambahan bobot badan harian antara perlakuan $\mathrm{T} 0, \mathrm{~T} 1, \mathrm{~T} 2$ dan T3 tidak menunjukan perbedaan yang nyata $(\mathrm{P}>0,05)$, akan tetapi berbeda nyata dibandingkan dengan perlakuan T4 dan T5 $(\mathrm{P}<0,05)$. Pemberian ransum T2 (60\% rumput lapang dan $40 \%$ silase limbah sayuran) mendapatkan respon terbaik dari domba lokal jantan dengan pertambahan bobot badan harian rata-ratanya sebesar 88,18 g/ekor/hari. Hasil penelitian ini lebih besar jika dibandingkan dengan hasil penelitian Kusumaningrum $d k k$. (2013) yang melaporkan bahwa pertambahan bobot badan harian dengan perlakuan ransum $60 \%$ rumput lapangan $+40 \%$ konsentrat + biosuplemen sebesar 80 g/ekor/hari. Pertambahan bobot badan harian berkaitan sekali dengan kandungan nutrien dari ransum yang diberikan.

Sementara itu, ransum pada perlakuan T4 dan T5 mengalami penurunan bobot badan dengan rataan nilai berturut-turut sebesar $(-33,00$ g/ekor/hari) dan (-127,00 g/ekor/hari). Hal ini diduga karena persentase pemberian silase yang terlalu banyak yang mengakibatkan bakteri asam laktat terlalu mendominasi rumen sehingga ketidakseimbangan bakteri tersebut menyebabkan kesehatan ternak terganggu. Hal tersebut dapat dilihat dari penurunan konsumsi pakan. Konsumsi pakan rendah menyebabkan asupan nutrisi pada domba semakin sedikit. Thalib (2000) menyatakan bahwa derajat keasaman asam laktat adalah yang paling asam dibandingkan dengan asam-asam organik lainnya yang terbentuk 
selama proses fermentasi. Penggunaan asam yang terlalu banyak dapat mengakibatkan pencernaan ternak terganggu.

Pencernaan merupakan sebuah proses metabolisme suatu makhluk hidup memproses sebuah zat dalam upaya mengubah secara kimia atau mekanik sesuatu zat menjadi nutrisi. Jika saluran pencernaan terganggu akan berdampak pada fisiologis ternak tersebut dan berpengaruh terhadap pola tingkah laku ternak kesehariannya dan hasil akhirnya ternak tidak akan berproduksi secara maksimal karena kesehatannya terganggu.

\section{Protein Daging}

Protein daging memiliki kemampuan untuk mengikat air. Kandungan protein yang tinggi akan meningkatkan kemampuan mengikat air daging dan menurunkan kadar air bebas, sehingga nutrisi daging yang hilang akan lebih sedikit. Rataan kadar protein daging domba lokal jantan disajikan dalam Tabel 2.

Data Tabel 2 menunjukan bahwa pemberian silase limbah sayuran sebagai substitusi pakan hijauan rumput berbeda nyata $(\mathrm{P}<0,05)$ terhadap kadar protein daging domba lokal jantan. Perbedaan kadar protein daging disebabkan karena perbedaan dan jumlah pakan yang dikonsumsi oleh domba. Pakan merupakan salah satu faktor yang mempengaruhi kadar protein daging.

Kadar protein hasil penelitian ini antara 18,39\% sampai 21,05\%. Rataan kadar protein hasil penelitian ini masih termasuk dalam kisaran normal. Soeparno (2005) menyatakan bahwa kadar protein daging berkisar antara 16-22\%. Purbowati $d k k$. (2006) melaporkan bahwa protein domba lokal jantan yang dipelihara di pedesaan pada bobot potong $20 \mathrm{~kg}$ yaitu 19,58\%. Selanjutnya Purbowati $d k k$. (2009) melaporkan bahwa protein daging domba yang digemukkan secara feedlot dengan pakan komplit berkadar protein dan energi yang berbeda yaitu antara $16,55-17,24 \%$. Hasil penelitian Sianturi (2015) yaitu protein daging pada domba Garut yang diberikan pakan berbasis sorgum adalah $19,11 \pm 1.52 \%$.

Kadar protein memiliki hubungan positif dengan kadar air, dimana protein daging dapat mengikat air, sehingga semakin tinggi kadar protein daging maka kecenderungan kadar air daging juga akan semakin tinggi. Kadar protein juga berhubungan dengan umur ternak. Domba lokal jantan yang diteliti memiliki umur $<1$ tahun. Pada umur ini berada pada fase pertumbuhan, yaitu pada fase pembentukan otot dan deposisi protein. Pembentukan protein di dalam tubuh umumnya dipengaruhi oleh status fisiologis ternak yaitu ternak yang masih muda membutuhkan lebih banyak protein dibandingkan dengan ternak dewasa (Arnim, 1996).

\section{Sifat Fisik Daging \\ a. Warna Daging}

DeMan (1997) menyatakan bahwa kualitas daging dapat ditentukan oleh faktor warna meskipun tidak mempengaruhi nilai gizi. Warna daging merupakan salah satu kriteria penilaian mutu daging yang dapat dinilai langsung oleh konsumen dan dideteksi oleh mata. Rataan nilai warna daging domba lokal jantan yang diberi pakan silase limbah sayuran dapat dilihat pada Tabel 3.

Tabel 2. Kadar Protein Daging Domba Lokal Jantan

\begin{tabular}{lcccccc}
\hline Parameter & T0 & T1 & T2 & T3 & T4 & T5 \\
\hline Kadar Protein $(\%)$ & $19,18^{\mathrm{a}}$ & $19,96^{\mathrm{b}}$ & $21,05^{\mathrm{c}}$ & $20,11^{\mathrm{b}}$ & $18,95^{\mathrm{c}}$ & $18,39^{\mathrm{d}}$ \\
\hline
\end{tabular}

Keterangan : Superskrip yang berbeda pada baris yang sama menunjukan perbedaan yang nyata $(\mathrm{P}<0,05)$

Data warna daging yang diperoleh menunjukkan nilai yang tidak berbeda nyata $(\mathrm{P}>0,05)$ dengan rataan 1,00-1,10 yang berarti pemberian silase limbah sayuran sebagai substitusi hijauan rumput tidak mempengaruhi warna daging domba lokal jantan. Warna daging pada penelitian ini tergolong merah muda. Soeparno (2005) menyatakan warna daging dipengaruhi oleh pakan, spesies, bangsa, umur, jenis kelamin, stres,pH serta oksigen. Perbedaan warna daging disebabkan oleh perbedaan konsentrasi mioglobin. Konsentrasi pigmen mioglobin tergantung pada jenis dan fungsi otot, umur, jenis kelamin, spesies dan bangsa ternak.

Mioglobin merupakan bentuk kimia urat daging terpenting yang berhubungan dengan warna daging segar. Walaupun hanya terdapat dipermukaan namun pigmen ini sangat penting menampilkan warna merah yang disenangi konsumen. Warna merah cerah akan kelihatan dominan apabila rasio oksimioglobin dan mioglobin seimbang yang berarti kira-kira $84 \%$ dari total kedalaman penetrasi oksigen (Lawrie, 2003). Sedangkan Soeparno (2005) menyatakan bahwa adanya ikatan oksigen pada atom besi $(\mathrm{Fe} 2+)$ pada struktur molekul mioglobin menyebabkan munculnya warna merah cerah pada daging.

Pengujian warna daging dilakukan pada daging bagian rusuk ke 12 dan 13 (daging loin). Warna daging pada penelitian ini tergolong merah muda. Menurut Soeparno (2005), warna daging 
dapat berubah menjadi merah terang apabila kontak langsung dengan udara luar. Perubahan warna disebabkan adanya oksigenasi mioglobin ungu membentuk oksimioglobin merah terang yang disebut dengan bloom. Purbowati $d k k$. (2006) melaporkan bahwa semakin tinggi bobot potong domba lokal maka warna daging pada bagian Longissimus dorsii semakin merah gelap.

\section{b. Susut Masak Daging}

Susut masak daging yaitu perbedaan antara bobot daging sebelum dan sesudah dimasak dan dinyatakan dalam persentase. Susut masak merupakan fungsi dari temperatur dan lama pemasakan. Susut masak selama proses pemasakan merupakan salah satu indikator nilai nutrisi daging, semakin besar susut masak daging maka nutrisi daging yang hilang akan semakin besar. Rataan susut masak daging domba lokal jantan yang diberi silase limbah sayuran dapat dilihat pada Tabel 3 .

Hasil analisis ragam menunjukkan bahwa pemberian pakan silase limbah sayuran tidak berbeda nyata $(\mathrm{P}>0,05)$ terhadap nilai susut masak daging domba lokal jantan. Nilai susut masak hasil penelitian yang telah dilakukan berkisar antara $28,57 \%$ - 30,45\%. Nilai susut masak daging domba lokal jantan tersebut dikategorikan kualitas yang baik dan layak untuk dikonsumsi. Hal ini sesuai dengan Soeparno (2005) yang menyatakan bahwa susut masak daging yang normal umumnya bervariasi antara $15 \%-54,5 \%$.

Hasil penelitian ini tidak berbeda jauh dengan hasil yang didapat Ramadhan (2010) pada daging domba lokal jantan yang dipelihara secara intensif yang memiliki rataan susut masak yaitu $34,93 \%$. Riyadi (2008) juga melaporkan bahwa susut masak daging domba yang diberi pakan ransum komplit dan hijauan dengan persentase yang berbeda yaitu antara 31,26\% - 34,50\%.

Soeparno (2005) menyatakan bahwa susut masak dapat dipengaruhi oleh $\mathrm{pH}$, panjang sarkomer serabut otot, panjang potongan serabut otot, status kontraksi myofibril, ukuran dan berat sampel daging serta penampang lintang daging. Menurut Shanks $d k k$. (2002) besarnya susut masak dipengaruhi oleh banyaknya kerusakan membrane seluler, banyaknya air yang keluar dari daging, umur daging, degradasi protein dan kemampuan daging untuk mengikat air. Daging dengan susut masak yang lebih rendah mempunyai kualitas yang relatif lebih baik daripada daging dengan susut masak yang lebih besar, karena kehilangan nutrisi selama pemasakan lebih sedikit.

\section{c. pH Daging}

Ternak dipuasakan terlebih dahulu selama 24 jam sebelum dipotong. Pemotongan dilakukan pada pagi hari untuk mengurangi tingkat stres ternak. Pengukuran nilai rataan $\mathrm{pH}$ dilakukan 24 jam setelah pemotongan untuk mengetahui $\mathrm{pH}$ akhir yang dicapai pada saat kandungan glikogen daging benar-benar habis. Rataan $\mathrm{pH}$ daging domba lokal jantan yang diberi pakan silase limbah sayuran dapat dilihat pada Tabel 3.

Tabel 3. Sifat Fisik Daging Domba Lokal Jantan

\begin{tabular}{lrrrrrr}
\hline Parameter & T0 & \multicolumn{1}{c}{ T1 } & \multicolumn{1}{c}{ T2 } & \multicolumn{1}{c}{ T3 } & \multicolumn{1}{c}{ T4 } & T5 \\
\hline Warna & 1,00 & 1,00 & 1,10 & 1,10 & 1,00 & 1,00 \\
Susut Masak (\%) & 30,14 & 28,72 & 28,57 & 28,81 & 30,45 & 30,39 \\
pH & 5,80 & 5,74 & 5,70 & 5,78 & 5,79 & 5,80 \\
\hline
\end{tabular}

Berdasarkan hasil yang diperoleh, pemberian pakan silase limbah sayuran pada domba lokal jantan tidak berbeda nyata $(\mathrm{P}>0,05)$ terhadap nilai $\mathrm{pH}$ daging. Rataan nilai $\mathrm{pH}$ daging domba lokal jantan adalah 5,74 - 5,80. Soeparno (2005) menyatakan bahwa nilai ultimat daging berada pada kisaran 5,4-5,8 setelah $12-24$ jam pemotongan. Hasil penelitian $\mathrm{pH}$ daging domba $5,74-5,80$ sesuai dengan pernyataan Soeparno (2005) berada pada $\mathrm{pH}$ ultimat, sehingga secara fisik daging yang dianalisa telah melewati fase rigormortis.

Hasil penelitian ini juga hampir sama dengan penelitian Sianturi (2015) pada domba Garut yang diberi pakan berbasis sorgum menghasilkan $\mathrm{pH}$ daging 5,79 $\pm 0,08$. Hal yang sama dilaporkan oleh Riyadi (2008) pada domba yang diberi ransum komplit dan hijauan dengan persentase yang berbeda menghasilkan $\mathrm{pH}$ daging $5,69 \pm 0,32-5,80 \pm 0,17$. Dihansih (2006) menyatakan bahwa nilai $\mathrm{pH}$ daging yang tidak berbeda kemungkinan disebabkan kandungan glikogen otot yang sama. Kadar glikogen yang sama menyebabkan ketersediaan asam laktat yang sama pada daging postmortem.

Soeparno (2005) juga menyatakan bahwa variasi $\mathrm{pH}$ daging dapat disebabkan stres sebelum pemotongan, pemberian injeksi hormon atau obat-obatan kimia tertentu, individu ternak, jenis otot, stimulasi listrik. Lawrie (2003) juga 
menegaskan bahwa tingkat penurunan $\mathrm{pH}$ pascamati dipengaruhi karena faktor instrinsik seperti spesies, tipe urat daging, variabilitas antara urat hewan serta faktor luar seperti pemberian obat-obatan sebelum dipotong dan suhu lingkungan.

\section{SIMPULAN}

Pemberian silase limbah sayuran sebagai substitusi hijauan rumput memberikan hasil yang berbeda nyata terhadap konsumsi bahan kering, pertambahan bobot badan harian dan protein daging, tetapi tidak memberikan hasil yang berbeda nyata terhadap kualitas fisik daging domba lokal jantan seperti warna, susut masak dan $\mathrm{pH}$ daging. Perlakuan terbaik yaitu pemberian pakan hijauan $60 \%$ dan silase limbah sayuran $40 \%$ dengan konsumsi bahan kering sebesar 720,38 g/ekor/hari, pertambahan bobot badan harian 88,18 g/ekor/hari, protein daging 21,05\%, warna daging merah cerah, susut masak $28,57 \%$ dan $\mathrm{pH}$ daging 5,70.

\section{UCAPAN TERIMA KASIH}

Peneliti menyampaikan terima kasih kepada Kementerian Riset, Teknologi dan Pendidikan Tinggi melalui Direktorat Riset dan Pengabdian Masyarakat yang telah memberikan dukungan pembiayaan penelitian tahun anggaran 2017 dan Pusat Penelitian dan Pengabdian (P3M) Universitas Majalengka.

\section{DAFTAR PUSTAKA}

Arnim. 1996. Daging: Sifat Fisik. Komposisi Kimia dan Kualitas. J. Peter. Lingk. 2: 4853.

DeMan, J.M. 1997. Kimia Pangan. Edisi kedua. Terjemahan: Padmawinata K. Institut Teknologi Bandung, Bandung.

Dihansih, E. 2006. Peningkatan mutu flavor daging yang dihasilkan dari domba yang diberi gula dan insulin pascatransportasi dengan waktu pemulihan yang berbeda. Disertasi. Sekolah Pascasarjana. Institut Pertanian Bogor, Bogor.

Durand, M. 1989. Conditions for Optimizing Cellulitic Activity in the Rumen in Evaluation of Straw in Ruminant Feeding. Elsevier Applied Science. London and New York.

Lawrie, R. A. 2003. Ilmu Daging. Terjemahan Aminuddin Parakkasi. Edisi kelima Universitas Indonesia Press, Jakarta.

Muktiani, A., J. Achmadi dan B. I. M. Tampubolon. 2007. Fermentabilitas
Rumen Secara In Vitro Terhadap Sampah Sayur yang Diolah. JPPT., 32 (1) : 44-50.

Nanda, D.D. 2011. Konsumsi Ransum dan Pertambahan Bobot Badan Sapi Bali yang Diberi Silase Daun Pelepah Kelapa Sawit sebagai Substitusi Rumput Gajah. Skripsi. Universitas Islam Negeri Sultan Syarif Kasim. Riau.

Permentan RI No. 57. 2006. Pedoman Pembibitan Kambing dan Domba yang Baik (good Breeding Practice). Jakarta.

Purbowati, E., C.I. Sutrisno, E. Baliarti, S.P.S. Budhi dan W. Lestariana. 2006. Komposisi Kimia Otot Longissimus dorsi dan Biceps femoris Domba Lokal Jantan yang Dipelihara di Pedesaan pada Bobot Potong yang Berbeda. Animal Production 8(1): $1-7$.

Purbowati, E., C.I. Sutrisno, E. BALIARTI, S.P.S. Budhi dan W. Lestariana. 2009. Komposisi Kimia Daging Domba yang Digemukkan Secara Feedlot dengan Pakan Komplit Berkadar Protein dan Energi yang Berbeda. Seminar Nasional Teknologi Peternakan dan Veteriner. Fakultas Peternakan Universitas Gadjah Mada. Yogyakarta.

Rahman, D. K. 2008. Pengaruh Penggunaan Hidrolisat Tepung Bulu Ayam dalam Ransum terhadap Kecernaan Bahan Kering dan Bahan Organik serta Konsentrasi Amonia Cairan Rumen Kambing Kacang Jantan. Skripsi. Program Studi Peternakan Universitas Sebelas Maret.

Ramadhan, F. 2010. Kualitas Daging Domba Lokal Jantan dengan Kecepatan Tumbuh Berbeda yang Dipelihara Secara Semi Intensif. Skripsi. Fakultas Peternakan, Institut Pertanian Bogor. Bogor.

Riyadi, S. Sifat Fisik dan Asam Lemak Daging Domba yang Diberi Pakan Ransum Komplit dan Hijauan dengan Persentase yang Berbeda. Skripsi. Fakultas Peternakan, Institut Pertanian Bogor. Bogor.

Shanks, B. C., D.M.Wolf, R.J. Maddock. 2002. Technical note: The Effect of freezing on Warner Bratzler Shear Force values of beef Longissimus steak across several postmortem aging periods. J. Animal Science 80: 2122-2125.

Sianturi, S.J. 2015. Kualitas Fisik, Kimia dan Histologi Daging Kambing Kacang dan Domba Garut yang Diberikan Pakan Berbasis Sorgum. Tesis. Sekolah Pascasarjana. Institut Pertanian Bogor. Bogor. 
Soeparno. 2005. Ilmu dan Teknologi Daging. Gadjah Mada University Press. Yogyakarta.

Steel, R.G.D. dan J.H. Torrie. 1993. Prinsip dan Prosedur Statistik Suatu Pendekatan Biometrik. Edisi Kedua, Gramedia, Jakarta. (Diterjemahkan oleh Bambang Sumantri).

Thalib, A., J. Bestari, Y. Widiawati, H. Hamid dan D. Suherman. 2000. Pengaruh Perlakuan Silase Jerami Padi dengan Mikroba Rumen Kerbau Terhadap Daya Cerna dan Ekosistem Rumen Sapi. JITV 5:1-6. 